\title{
Análise paratradutiva das diferentes edicións do Manifesto do Partido Comunista ao galego: a ideoloxía das marxes
}

\author{
Robert Neal Baxter \\ Universidade de Vigo
}

Data de recepción: 17/11/2017 | Data de aceptación: 17/01/2018

\begin{abstract}
Resumo:
Este artigo presenta o concepto de 'paratexto' e a súa utilidade práctica aplicada á análise tradutolóxica, concretamente sob o modelo de 'paratradución' acuñado e desenvolvido na Universidade de Vigo. Este marco teórico serve como ferramenta para analizar as oito versións do Manifesto do Partido Comunista publicadas en galego para tentar dilucidar cales poden ser as súas pretendidas funcións latentes, para alén da simple función comunicativa interlingüística. $\mathrm{O}$ artigo conclúe incidindo na importancia que teñen os paratextos para entender un texto traducido na súa globalidade, ao recalcar que, se ben se trata dunha mesma obra orixinal de partida, existen elementos que condicionan a recepción de cada tradución que as torna textos diferentes.
\end{abstract}

\section{Palabras chave:}

paratexto; paratradución; función; galego; Manifesto Comunista.

\section{Sumario:}

1. Introdución. 2. Máis alá da función comunicativa da tradución. 3. As edicións galegas. 3.1. Nova Galiza (1976). 3.2. Akal (1976). 3.3. Xerais (1998). 3.4. Abrente (1998). 3.5. Abrente (2004). 3.6. La Voz de Galicia (2005). 3.7. Fundación Federico Engels (2009). 3.8. Xerais (2015). 4. Conclusións.

\section{A paratranslational analysis of the different editions of the Manifesto of the Communist Party in Galizan: ideology on the margins}

\begin{abstract}
:
This paper presents the concept of 'paratext' and its practical utility as applied to traductological analysis, namely the 'paratranslation' model created and developed at the University of Vigo. This theoretical framework is used as a tool to analyse the eight existing editions of the Manifesto of the Communist Party in Galizan in order to elucidate the intended latent functions behind them, above and beyond the merely interlinguistic communicative function. The paper concludes by underlining the importance of paratexts in order to understand a translated text as a whole, stressing that while they all derive from the
\end{abstract}


same original source text, elements exist conditioning the way they are received, effectively rendering them different texts.

\section{Key words:}

paratext; paratranslation; function; Galizan; Communist Manifesto.

\section{Contents:}

1. Introduction. 2. Beyond the communicative function of translation. 3. Galizan language editions. 3.1. Nova Galiza (1976). 3.2. Akal (1976). 3.3. Xerais (1998). 3.4. Abrente (1998). 3.5. Abrente (2004). 3.6. La Voz de Galicia (2005). 3.7. Fundación Federico Engels (2009). 3.8. Xerais (2015). 4. Conclusions. 


\section{Introdución}

O obxectivo deste traballo consiste en presentar e analizar os elementos paratextuais (prólogos, epílogos, imaxes gráficos...) que, ademais do propio texto en si, conforman a tradución entendida na súa globalidade dunha das obras clásicas políticas e filosóficas que máis ten marcada a historia da humanidade. Compáranse as múltiplas versións actualmente existentes en galego para determinar até que punto un mesmo texto orixinal pode cumprir diferentes e mesmo contraditorias funcións como texto traducido.

O ano 2018 marcará o 170 aniversario da publicación do Manifesto do Partido Comunista, tamén coñecido simplemente como O Manifesto Comunista, un panfleto político que, a pesar das súas escasas 23 páxinas orixinais, foi -e segue a ser- sen dúbida unha das obras escritas máis influentes na historia recente da humanidade (Boyer, 1998: 151), que ostenta "un nivell d'erudició que no ha estat igualat en el camp de la història del pensament" (Argemí, 1999: 19). Taylor colócao non só ao mesmo nivel que $A$ orixe das especies de Darwin, mais chega a comparar a súa influencia coa da Biblia ou O Corán:

Thanks to The Communist Manifesto, everyone thinks differently about politics and society [...]. More than this, Marxism has become the accepted creed or religion for countless millions of mankind, and The Communist Manifesto must be counted as a holy book, in the same class as the Bible or the Koran. (Taylor, 1967: 7).

Publicado anonimamente en alemán en Londres, o 21 de febreiro de 1848, pola Asociación Educativa dos Traballadores, foi redactado por encargo da Liga dos Comunistas por Marx e Engels, cuxa identidade non foi revelada até dous anos despois na primeira tradución ao inglés de Helen Macfarlane. Despois de varias vicisitudes, o texto foi revisado o mesmo ano para eliminar erratas, dando lugar á versión corrixida de 30 páxinas que utilizaron Marx e Engels como base para todas as futuras edicións do Manifesto.

Consta dun preámbulo ("Un espectro percorre Europa: o espectro do comunismo [...]") e catro capítulos: Capitulo I: Burgueses e proletarios, onde se expón a concepción materialista da historia como a loita de clases. No capitalismo, o proletariado está asoballado pola burguesía. A loita de clases levará ineludibelmente a unha revolución coa toma de poder polo proletariado; Capitulo II: Proletarios e comunistas, que sitúa os comunistas conscientes en relación co resto da clase traballadora: o Partido Comunista defende os intereses do proletariado. Pecha cunha serie de reivindicacións a curto prazo, p.e., educación pública gratuíta, a nacionalización dos medios de trasporte... como antesala dunha sociedade sen 
clases; Capitulo III: Literatura socialista e comunista, onde se estabelece a diferenza entre o comunismo e os outros tipos de socialismo daquel momento; Capítulo IV: Posición dos comunistas fronte aos diversos partidos de posicións, que consiste nunha breve conclusión que describe a táctica que se debe seguir polas e polos comunistas en varios países de Europa. O Manifesto termina coa sonada exhortación que se difundiría anos máis tarde como lema da Unión Soviética: "Proletarios de todos os países, unídevos!”.

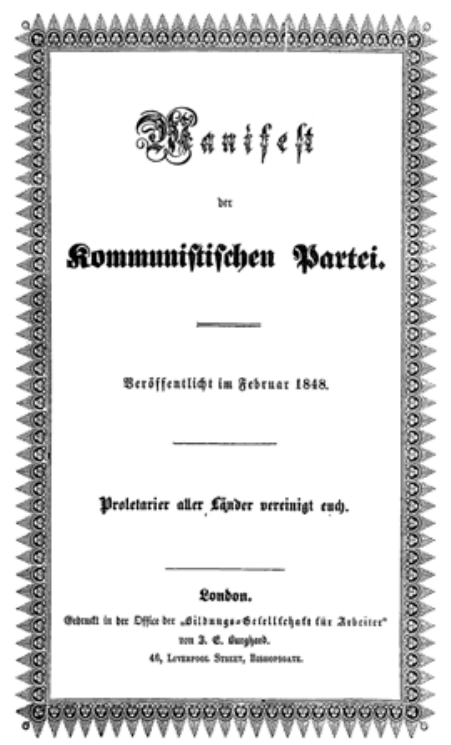

Fig. 1: Capa da primeira edición en alemán (1828).

\section{Máis alá da función comunicativa da tradución}

O Manifesto Comunista é dun dos libros máis traducidos da historia (Rich, 2015: sen páxina $)^{1}$, incluídas non só as principais linguas europeas e-como é de esperarmoitas linguas da ex-Unión Soviética e os países socialistas, mais tamén moitas linguas 'minorizadas', algunhas delas de recente data, entre elas o baixo alemán (2012), o bretón (1978), o córnico (2016), o galés (1948), o irlandés (1986), o occitano (1976)... sen falar do catalán, o vasco ou o propio galego.

$1 \mathrm{O}$ sitio Comintern (S-H) rexistra 75 linguas, ás cales se poden sumar o bretón, occitano, irlandés, galés... (http://ciml.250x.com/archive/marx_engels/me_languages.html) 
A súa tradución ten unha notábel traxectoria nas linguas non-castelás do Estado español, sobre todo o catalán, cuxa primeira versión se remonta a 1930. Existe un total de nove versións nesta lingua e varias reedicións (véxase Gasch Grau (1975) e Mota Muñoz (2010) para os períodos 1872-1939 e 1930-1948 respectivamente), cinco en vasco e unha en asturiano (véxase o Apéndice).

Son oito as edicións publicadas até a data en galego (incluídas varias reedicións) que se describen e analizan en detalle a continuación. Tan só dúas delas -as máis antigas (Nova Galiza e Akal)- utilizan o título completo do orixinal Manifesto do Partido Comunista, en canto que as cinco restantes optan pola forma abreviada O Manifesto Comunista (Xerais, La Voz de Galicia e Fundación Federico Engels) ou, simplemente, Manifesto Comunista sen artigo (Abrente).

Ao definir o concepto de 'tradución', sitios de consulta populares como Wikipedia recollen a concepción extremadamente estendida de que se trata dun proceso esencialmente comunicativo que facilita a comprensión entre falantes de linguas diferentes:

A tradución [...] é unha actividade que comprende a interpretación do significado dun texto nun idioma, chamado texto orixe, a un texto equivalente noutro idioma, chamado texto meta. Tamén o produto desta actividade, o texto meta, denomínase tradución.. (Entrada 'Tradución' na Galipedia)

Ora ben, é obvio que unha visión tan utilitarista non ten sentido no caso de linguas como o galego desde o momento en que a obra en cuestión xa existe nunha versión en lingua española -tal é o caso do Manifesto desde 1872 (Gasch Grau, 1975: 22)-, xa que todas as persoas que falan galego tamén entenden o español:

[...] we have to acknowledge that even as a communicative activity, translation is not always associated with a lack of understanding. When a given company makes the decision to have its advertisements or the labels of its products translated into the minority language of a state, such decision (sic) is not motivated by the inability of the recipients to understand the major language. (García González, 2005: 107)

As razóns que motivan a tradución do Manifesto ao galego hai, pois, que buscalas noutra orde de explicacións que non sexa de tipo exclusivamente comunicativo ou utilitarista, como pode ser garantir o dereito de as persoas galegofalantes viviren plenamente na súa lingua e a planificación do status lingüístico (Baxter, 2013); promover a identidade nacional (Woodsworth, 1996); axudar a crear un corpus literario propio (Cruces, 1993)...

Nos anos 80, Genette (1987: 7-8) acuñou o termo 'paratexto' como un dos cinco tipos de transtextualidade (intertextualidade, metatextualidade, hipetextualidade e 
arquitextualidade, véxase Yuste Frías, 2015: 320) que define nos seguintes termos: "Le paratexte est donc pour nous ce par quoi un texte se fait livre et se propose comme tel à ses lecteurs, et plus généralement au public" (Genette, 1987: 7-8). Este paratexto, que se divide, á súa vez, entre peritexto e epitexto, fai referencia:

al acompañamiento de un texto por formas discursivas, icónicas, verbo-icónicas o puramente materiales que lo introducen, presentan, rodean, acompañan y envuelven materialmente en su propio suporte (peritexto) o la prolongación fuera del suporte físico en el que es editado (epitexto). (Yuste Frías, 2015: 320)

Resulta ser de sumo interese a aplicación do concepto de paratextualidade de Genette ao campo da análise tradutolóxica para entender a tradución na súa globalidade, xa que en palabras de Yuste Frías (2015: 327) “[ ... no puede haber texto traducido sin sus correspondientes paratextos traducidos. [...] sin paratexto, el texto no existe". Isto levou á creación na Universidade de Vigo do termo 'paratraduction' (Yuste Frías, 2015: 321), concepto a respecto do cal Nord (2012: 407) indica: "it is obvious that the concept of paratranslation can trigger exciting research questions".

Unha análise paratradutiva como a que propón este artigo, que tome en conta todos aqueles elementos que gravitan ao redor da tradución como produto físico global que fan que a lectora a identifique - consciente ou inconscientemente- cunha determinada función: "El enfoque paratraductivo de la traducción estudia cómo los paratextos pueden influir enormemente sobre la manera en que un nuevo público percibe una literatura traducida [...]" (Yuste Frías, 2015: 322), pode servir para dilucidar cales son as motivacións que se agochan detrás de cada texto traducido.

Garrido Vilariño explica como os elementos paratextuais que rodean e acompañan un texto poden condicionar quen pensa comprar ou ler unha determinada obra co seguinte exemplo hipotético:

[...] un lector entra nunha libraría e compra unha obra literaria da que non coñecía nada nin sobre o autor nin sobre o argumento dela. [...] o lector mirou a capa (ou sobrecuberta) e gustoulle o título e a imaxe ou imaxes que aí aparecen e que, ademais, o informan da adscrición xenérica da obra. Logo leu a capa posterior onde se recolle un sucinto resumo argumental e unha serie de recensións realizadas por autores de recoñecido prestixio ou por xornais especializados en que se loa a calidade do libro e quedou atraído polo tema e convencido pola solvencia das autoridades que o referendan. A seguir, fixouse nas lapelas interiores e informouse da traxectoria artística do autor e para rematar recorreu [sic] á páxina de dereitos e descubriu que estaba perante unha obra traducida. Pois ben, a súa fonte de información previa fundamental non foi o texto literario, senón os elementos que o arrodean, é dicir, o/s paratexto/s. Garrido Vilariño (2005: 31) 
Deste xeito, a pesar de se tratar da 'mesma' obra, isto é $O$ Manifesto do Partido Comunista, as diferentes edicións e traducións poden presentar notábeis diferenzas segundo a función que se pretende que desempeñen. Véxase, por exemplo, en lingua inglesa: edicións intencionadamente económicas (Penguin Little Black Classics. 2015); edicións conmemorativas (The Communist Manifesto - Centenary Edition. Lawrence e Wishart. 1948) e de luxo (Penguin Classics Deluxe Edition. 2011); en formato cómic (The Communist Manifesto Illustrated. Red Quill Books. 2016); adaptado a un inglés sinxelo e moderno (The Communist Manifesto in Plain and Simple English. BookCaps. 2012); de capa branda e de capa dura...

A continuación, preséntanse e analízanse varios elementos presentes nas oito edicións e reedicións actualmente dispoñíbeis do Manifesto Comunista en galego, contrastándoas e situándoas cada unha na súa ostensíbel intencionalidade ideolóxica. Máis concretamente, as análises céntranse sobre todo nunha serie de peritextos definidos como: “[...] tous les éléments paratextuels qui entourent, enveloppent et accompagnent le texte dans un espace qui reste compris à l'intérieur de la publication éditée, sur le même support et donc indissociable à lui." (Yuste Frías, 2010: 289), nomeadamente, a colección a que se asigna cada edición, a súa capa, contracapa e solapas e outras imaxes interiores e os prólogos e as introducións que conteñen. Tamén se analizan, sempre que sexan pertinentes, determinadas escollas ortográficas heterodoxas.

\section{As edicións galegas}

A modo de introdución, o tratamento que reciben os prólogos orixinarios do Manifesto, isto é, os redactados quer por Marx e Engels xuntos, quer por Engels só $^{2}$, serve de excelente exemplo das discrepancias paratextuais que existen entre as diferentes edicións publicadas en galego. Pois, se ben todas as versións do Manifesto do Partido Comunista en galego inclúen os mesmos sete prólogos 'canónicos', aínda cunhas moi lixeiras diferenzas sen maior importancia ${ }^{3}$, existe unha discrepancia esencial en canto ao lugar que ocupan a respecto do corpo do texto principal.

2 Por orde cronolóxica: Prólogos ás edicións en alemán 1872 (Marx e Engels); ruso 1882 (Marx e Engels); alemán 1883 (Engels); inglés 1888 (Engels); alemán 1890 (Engels); polaco 1892 (Engels); italiano 1893 (Engels).

3 Nova Galiza e Akal optan por agrupar os prólogos por linguas, mentres que as restantes edicións utilizan a orde cronolóxica, máis habitual neste caso. No índice de Akal, o prólogo á edición rusa de 1882 aparece como "Prá edición noutras linguas», se ben o prólogo en si na páxina 21 leva por título "Limiar prá oustra (sic) lingua (Prá segunda edición rusa, 1882)». As edicións de Abrente recollen só "Prefacio à edizón italiana» e "Prefácio à ediçom italiana» sen precisar a data (1893). Tan só as edicións de Xerais recollen o título completo "Ao lector italiano [Limiar á edición italiana de 1893]». 
A pesar de que na edición orixinal en alemán se utilizan as palabras Vorwort e Vorrede ('prólogo, preámbulo...'), xa que preceden o texto principal, e a pesar de todas as edicións utilizaren os sinónimos 'limiar' (Akal, Xerais), 'prefacio' (Abrente, Fundación Federico Engels), 'prólogo' (Nova Galiza), que indican claramente que deben preceder o texto, tanto as edicións de Xerais (incluída a reedición de La Voz de Galicia) como a da Fundación Federico Engels colócanos despois do texto principal. Esta secundarización indica que se debe ler o texto principal antes dos prólogos correspondentes, que pasan a ser simples anexos optativos, independentemente da autoría dos mesmos (Marx e Engels). De feito, na edición da Fundación Federico Engels aparecen no índice como meros 'Apéndices'.

As edicións de Abrente inclúen un Prólogo do Comité Central de Primeira Liña $(M L N)$, ao cal se engade un Prólogo à ediçom galega de 2003 na segunda edición case co mesmo rango que os prólogos orixinarios con títulos moi parecidos, coa única diferenza entre eles o uso dos termos 'prólogo' (propio) face a 'prefácio' (orixinal).

Finalmente, tanto a edición da Fundación Federico Engels como as de Xerais optan por separar os seus respectivos Limiar e Introdución escritos por coñecidos teóricos alleos á editorial (Alan Woods e Ramón Máiz Suárez, véxase máis adiante) dos prólogos orixinarios, aparecendo ao principio da obra. Esta colocación indica que se consideran máis importantes para unha correcta lectura posterior do texto por parte dunha lectora galega do que os prólogos orixinais, destinados ás lectoras de linguas estranxeiras (alemán, inglés, italiano, polaco ou ruso).

\subsection{Nova Galiza (1976)}

Esta versión publicada por Nova Galiza o 16 de xaneiro de 1976 é a tradución máis antiga do Manifesto en galego: "E a primeira vez que $O$ Manifesto Comunista se publica en lingua galega. A iniciativa débese a-o Partido Comunista de Galicia." (limiar, sen páxina)

O libro reviste unha capa onde predomina a cor vermella, cor do comunismo, e un gravado anónimo en branco e negro de Marx inspirado nun dos seus retratos fotográficos máis coñecidos onde se ve sentado co cóbado pousado nunha mesa.

Forma parte dunha colección denominada Clásicos do marxismo. Segundo se pode ler ao final do libro, o outro volume da mesma colección foi El Pensamiento Político de Castelao de Alberto Míguez (1975, reedición de Ruedo Ibérico de 1965) e dous próximos títulos: Contra el continuismo franquista (Por la libertad. Por la 
autonomía de Galicia) do fundador da federación galega do Partido Comunista de España, Santiago Álvarez (1976), e Castelao - Vida e Obra, do membro do Partido Galeguista no exilio Xosé Núñez Búa, que todo indica que non chegou a publicarse. Trátase, pois, dunha colección -aínda que moi reducida- de marcado carácter político vinculado á vez ao PCE e ao galeguismo.

Despois da folla de rostro, aparece na primeira páxina da esquerda un brevísimo texto introdutorio onde se deixa claro desde o primeiro momento o propósito explicitamente político da publicación: "Coidamos que con a sua publicación contribuimos asinaladamente a difusión do marxismo antre o pobo galego e moi en especial da sua mocedade."

$\mathrm{Na}$ liña final deste textiño preliminar, indícase que a tradución foi realizada por un militante do Partido Comunista de Galicia, identificado como Xoan (sic) Andeiro. Segundo a tese do Comité Central de Primeira Liña (MLN) que se recolle no prólogo na primeira edición do Manifesto publicado por Abrente (p. 14), trataríase do "provável nome de guerra adoptado pol@ autor/a ou autores/as." No entanto, Ana Luna Alonso (2006: 194) considera que se trata do "seudónimo (sic) do músico e profesor Xoán Trillo", hipótese avalada por Máiz Suárez na súa introdución á edición de Xerais do Manifesto (1998: 29). Todo tende a apuntar a que se trataría de Joám Trilho, actualmente membro numerario da Academia Galega da Língua Portuguesa (AGLP) e "membro fundador do grupo dos Irmandiños en Roma" segundo se recolle na páxina oficial da AGLP, o que deixa pensar que podería ser a mesma persoa a que alude Pérez Prieto (sen data: 6) na súa breve biografía de Ramón Valcarce Vega: “[...] no grupo dos teólogos galegos en Roma [...] un dos curas chegou a militar logo no PCE, Joám Trillo; fala del sen nomealo, X. A. Martínez García no seu traballo A Igrexa antifranquista en Galicia (1965-1975)." Sexa como for, o uso dun pseudónimo indica que perduraba a necesidade da clandestinidade no período despois da morte do ditador, polo que a iniciativa deste primeiro Manifesto saíu da 'Galicia da Diáspora' (contracapa da edición publicada por Akal) e publicado concretamente en Lisboa, segundo o Catálogo Iacobus da Universidade de Santiago de Compostela.

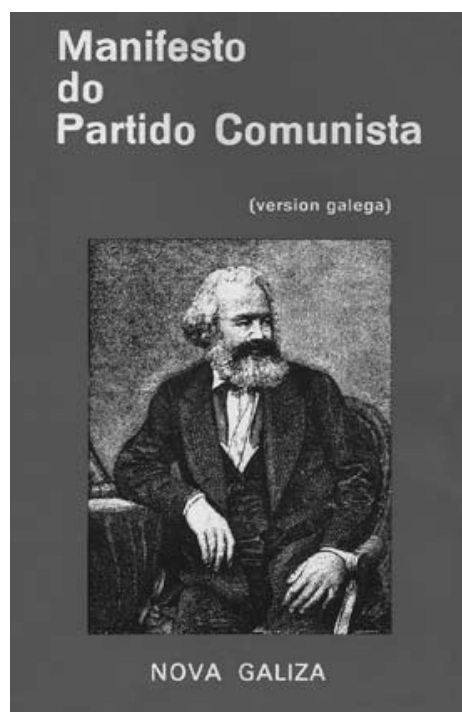

Fig. 2: Capa da edición de Nova Galiza, 1976 (12 x $18 \mathrm{~cm} .121$ páxinas). 
A continuación, na páxina oposta, inmediatamente antes dos prólogos, áchase outro texto curto, cuxa extensión non excede os dous parágrafos, onde se explica cal foi a edición orixinal en alemán que serviu de texto de partida, indicando que se inclúen tanto as notas orixinais de Engels como outras propias da redacción, diferenciadas entre elas mediante asteriscos e números respectivamente. En total son 82 as notas da redacción, todas elas de tipo técnico (esclarecementos historicistas, puntualizacións a respecto da tradución de determinados termos alemáns...).

Este escasos parágrafos constitúen os elementos paratextuais escritos máis destacados, xa que conforman o primeiro elemento con que entra en contacto a lectora e, a pesar da súa brevidade, serven para colocar en primeiro plano o facto de se tratar dunha publicación explicitamente política -comunista e galeguistapatrocinada e avalada directamente polo Partido Comunista de Galicia, federado ao PCE, cuxo nome non aparece, posibelmente para facer fincapé no aspecto galego.

Esta é de lonxe a edición que máis ilustracións contén, xa que se reproducen catro imaxes dentro do libro: a primeira páxina da "última edición do Manifesto (1890) que Engels coidóu" (p. 17); a "edición inglesa do Manifesto do 1888 autorizada por Engels" (p. 29), ambas inseridas xusto antes do prólogo correspondente; e a capa da primeira edición en alemán de 1884 que aparece, como vén sendo habitual, inmediatamente antes do propio texto (p. 45). A cuarta imaxe é unha reprodución da "Única páxina manuscrita conservada do proxeito do Manifesto do Partido Comunista. Autógrafo de Karl Marx." (p. 93) que aparece xusto antes da tradución deste, que corresponde ao primeiro dos tres Apéndices. O segundo constitúeo a tradución do "Rascuño do plan do III Capítulo do Manifesto do Partido Comunista" e o terceiro consiste nun "Catálogo de todas as edicións curadas e autorizadas por Marx e Engels".

A obra termina cun índice onomástico que recolle unha cincuentena de nomes propios (persoas, lugares, xornais...) que figuran no texto, algo habitual nas publicacións da Editorial Progreso (véxase máis adiante, Sección 3.2).

\subsection{Akal (1976)}

Publicada no mesmo ano que a anterior, a edición de Akal é posterior a esta, tal e como se indica na contracapa. Aínda que afincada en Madrid, a editorial Akal, fundada polo coruñés Ramón Akal González, sempre estivo vinculada coa esquerda e coa Galiza, como testemuñan certas obras editadas, entre elas os 50 tomos da $\mathrm{Obra}$ Completa de Lenin, a Obra Completa de Castelao en galego en 3 tomos (19811990), así como Nós (1990), As cruces de pedra na Galiza (1990), Galicia mártir (1989), Milicianos (1989) ou Atila en Galicia (1984). 
O Manifesto intégrase como o número 20 dentro da colección Arealonguiña, recoñecíbel polo seu formato sinxelo con capa vermella e encadernación rústica, dirixida por Xesús Alonso Montero, militante do Partido Comunista Español (PCE) desde $1962^{4}$.

A variedade dos títulos na colección, desde poesía, obras de referencia, ficción e ensaio tanto en galego como (aínda que moi marxinalmente) en español, testemuñan o cerne galeguista que a artella, desde Seis poemas galegos de Federico García Lorca (1974), Pedro Petouto: Traballos e cavilaciós dun mestre subversivo (1974) do propio Alonso Montero ou $O$ clero na literatura popular galega. Cancioneiro e refraneiro do Equipo A.P. (1975), O soño sulagado de Celso Emilio Ferreiro (1975) e $O$ bendito San Amaro de Ramón Cabanillas e Alfonso Daniel Castelao, (Edición facsímile, 1975), pasando polo Estatuto de Autonomía pra Galicia 1936. Comentarios de Castelao 1948. (1976), Dependencia y discriminación escolar en Galicia (1979) de José Pérez Vilariño, Galicia. Catro documentos sociopoliticos (1978) de VV.AA. e o facsímile da Gramática

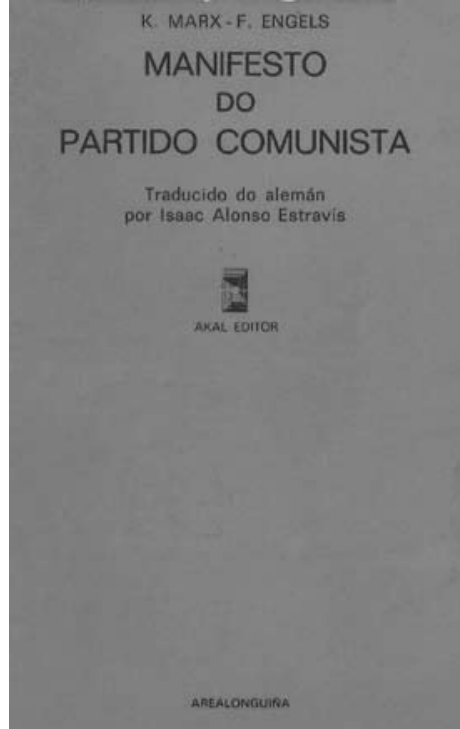

Fig. 3: Capa da edición de Akal, 1976 (10,5 x $17 \mathrm{~cm} .101$ páxinas). de Francisco Mirás de 1864 (1978).

O texto foi traducido do alemán por Isaac Alonso Estravís. Mais, por ser moi anterior á normativización actual do galego, o tradutor recorre a un galego marcadamente diferente dos 'mínimos', polo cal é coñecido como autor do Dicionário da língua galega (Sotelo Blanco, 1995), antes de pasar ao portugués padrón, sendo actualmente membro numerario da Academia Galega da Língua Portuguesa. O tipo de galego que se utiliza ten un claro afán enxebrista e hiperdiferencialista a respecto do español, mais sen as implicacións ideolóxico-políticas fronte a outras normativas, como vai ser o caso noutras edicións analizadas (véxase as edicións de Abrente máis adiante). O tipo de galego permite situar a tradución no tempo e nun momento concreto do proceso de normalización lingüística e coloca o tradutor nun momento concreto da súa evolución en canto ao proceso da codificación e normativización do galego.

4 Biblioteca de Galicia (http://bibliotecadegalicia.xunta.gal/es/catalogos-coleccions/biblioteca-de-xesus-alonso-montero) 
A cobertura non contén ningún elemento pictórico ou simbólico, xa que todos os libros da colección revisten a mesma capa sinxela sen ningún tipo de adornos para alén do anagrama da editorial. O feito de se utilizar a cor vermella neste caso non reviste unha relevancia particular, ao tratarse da mesma cor que se utilizou para toda a colección.

Nas primeiras páxinas, reprodúcense fotografías en branco e negro, primeiro de Carlos Marx e logo de Federico Engels, idénticas aos retratos asociados cos opúsculos editados pola soviética Editorial Progreso, en particular a edición española do Manifiesto del Partido Comunista de 1976, editorial de referencia para calquera militante comunista da época que se dedicaba a publicar e divulgar clásicos soviéticos do marxismo-leninismo ao redor do mundo en até 50 linguas. Así mesmo, inmediatamente antes do texto do propio Manifesto, reprodúcese, como vén sendo habitual, a capa da primeira edición do Manifesto en alemán de 1848.

O facto de todas as versións (excepto as de Xerais e a reedición de La Voz de Galicia) seguiren as pautas marcadas por esta editora -cunha similitude máis que notoria no caso da edición de Akal- non pode ser casual, dado o grao de penetración da Editorial Progreso e o seu prestixio como editorial comunista 'oficial', isto é, da Unión Soviética. Deste xeito, ao partillaren este formato paratextual moi recoñecíbel, á súa vez, as edicións galegas tamén podían gozar do mesmo prestixio. Xa desaparecida a URSS, en grande medida, outras edición de corte 'político', nomeadamente Abrente e a Fundación Federico Engels, van emular o mesmo formato.

A contracapa recolle un breve textiño explicativo asinado por X.A.M. (Xesús Alonso Montero) que abre cunhas liñas de fondo contido político, combinando a loita do pobo galego asoballado coa loita para a emancipación social, facendo fincapé ante todo na Galiza e no seu pobo como "Un país marxinado, unha xente labrega, emigrante e mariñeira, unha Terra esmagada polos fadairos da historia [...]" a quen apela "O gran Chamamento de Carlos Marx e Federico Engels -portavoces precisos i engaiolantes da xente que sofre a historia, da grei asoballada [...]", insistindo en que se trata dun "Chamamento que, sendo de 1884, aínda chama, aínda nos chama [...]". Despois, pasa a indicar que se trata da segunda edición do Manifesto na "lingua proletaria do meu pobo" (citando, sen o especificar - por se dar por abondo coñecida-a poesía Deitado frente ao mar de Celso Emilio Ferreiro), engadindo que a edición anterior saíse na "Galicia da Diáspora ([en] datas máis bravas) [...]. Agora abrolla de entre nós unha traducción [do Manifesto]", obviando que a editora Akal está afincada en Madrid. Finalmente, termina constatando que "A literatura galega conta xa cun novo "clásico" mais que segue a ser vixente como "unha ferramenta máis, un esconxuro máis pra escorrentarmos a 'fantasma' da Dereita [...]”. 


\subsection{Xerais (1998)}

Houbo que esperar máis de 20 anos despois da aprobación da normativa ILG-RAG até que a editorial xeneralista (isto é, nin especializada en literatura política nin ligada a ningunha organización política) Xerais sacase unha versión en galego nesta normativa "oficial". Foi traducida directamente do alemán por Franck Meyer, tradutor de varias outras obras literarias do alemán ao galego 5 .

Publícase dentro da reducida subcolección dos libros de peto De-liberacións, xunto con outros textos filosóficos clásicos curtos: Discurso do método de Descartes (trad. Miguel Vázquez Freire, 2001); Lombroso $e$ os anarquistas de Ricardo Mella (trad. Valentín Arias, 1999); Cándido de Voltaire (trad. Henrique Harguindey, 1999); A lenda do grande inquisidor de Fiódor Dostoievski (trad. Alexandra Koss, 2007); Banquete de

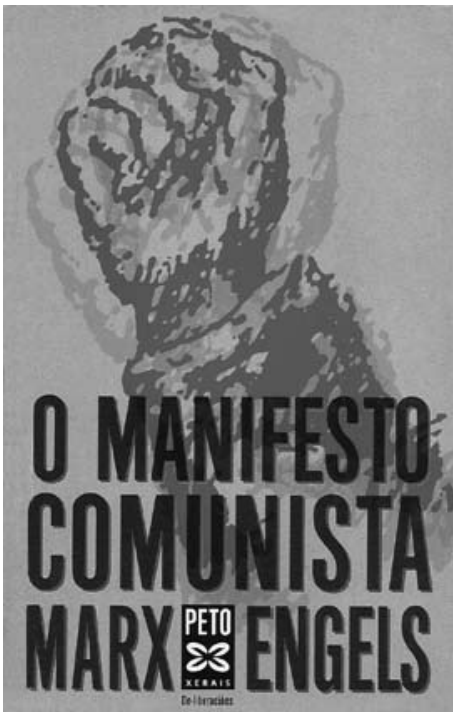

Fig. 4: Capa da primeira edición de Xerais, 1998 (11 x 17,5 cm. 117 páxinas). Platón (trad. Juan Carlos Búa Carballo, 2005).

Esta e as súas seguintes reedicións (Xerais e La Voz de Galicia) son as únicas edicións en galego que non levan ningunha ilustración interior. A contracapa si está ocupada pola imaxe dun puño ergueito, símbolo da loita e da resistencia, de cor vermella, asociada co comunismo, cun fondo de cor amarela, a cor secundaria que se relaciona co comunismo a través da bandeira da Unión Soviética. Á diferenza da imaxe que se escolleu para a segunda edición que se analiza máis adiante, esta imaxe transmite a idea de que se trata dunha obra non só de pensamento filosófico teórico, senón de loita, como indica Argemí (1999: 18): “[...] el Manifest no és, principalment, un document teòric. És un programa d'acció política.” Esta primeira impresión compleméntase co texto que aparece na contracapa.

Xunto co lombo que se ve antes de seleccionar unha obra aínda no andel -en todas as edicións de cor vermella, cor do comunismo e/ou simplemente da colección en cuestión segundo o caso-, a capa e a contracapa, que se presentan á lectora cando xa o ten entre as mans, funcionan como o cartón de visita dun libro. Eis a importancia

5 Véxase a súa ficha na Biblioteca da Tradución Galega (BITRAGA): http://bibliotraducion.uvigo.es/ autores_ver.php?autor $=1373$ 
que revisten tales elementos paratextuais como condicionantes da recepción dunha obra antes mesmo de que a lea a lectora: “[...] tenant pour acquis qu'avant même d'avoir lu un livre, un lecteur potentiel s'est vraisemblablement déjà fait une idée de son contenu à partir de l'effet que son paratexte aura eu sur lui [...]" (Straford e Jolicoeur, 2014: 99-100):

Como no resto da colección, a contracapa leva un extracto dun autor coñecido referido á obra en cuestión, neste caso Juan Ramón Capella, extraído de Leer el Manifiesto $H o y^{6}$ onde se cualifica o Manifesto de "clásico do movemento emancipatorio" que se inspira no "aborrecemento da inxustiza" e debuxa tres ideas centrais referidas ao modo económico de produción en relación á estrutura social; a loita de clases e a liberación da "clase explotada e oprimida". A diferenza dos outros elementos paratextuais analizados, este marca o Manifesto non só como un clásico, mais como un texto político e liberador.

Cómpre indicar que, se ben "No milita en ningún partido, pero se siente 'próximo a la gente del PCE y de Izquierda Unida""7, Juan Ramón Capella Hernández, catedrático emérito de Filosofía do Dereito, Moral e Política da Universitat de Barcelona, tamén é membro do consello editorial de Mientras Tanto $^{8}$, revista da Fundació Giulia Adinolfi-Manuel Sacristan, da cal é patrón ${ }^{9}$, sendo este último, no seu día, membro da dirección executiva do Partido Socialista Unificado de Cataluña (PSUC), federado ao Partido Comunista de España (PCE). Así, pois, e de maneira sutil para quen tomar as molestias de indagar, as edicións de Xerais fican vinculadas ás versións anteriores de Nova Galiza e Akal, que se citan, por outra parte, na sección Algunhas lecturas complementarias (p. 29).

A relación estréitase cando se sabe que, xunto cun prólogo de Francisco Fernández Buey, tamén ex-militante do PSUC, Capella foi o autor do epílogo dunha versión en lingua española do Manifesto publicado en 1998 por Utopías/Nuestra Bandera, editora da Fundación de Investigaciones Marxistas, unha "entidad cultural privada promovida por el Partido Comunista de España"10.

6 A referencia aparece con data de 1993, mais sen citar máis fontes, nin aparece recollido nas Lecturas complementarias. A única referencia dunha obra con este título deste autor que se localizou foi un artigo dispoñíbel no blog Marx desde Cero (https://kmarx.wordpress.com/2012/01/13/leer-el-manifiestocomunista-hoy/).

7 Primera escuela de octubre. Comisiones Obreras de Asturias (http://www.fundacionjuanmunizzapico. org/EscuelaDeOctubre/2009/2009_05.htm)

8 Mientras Tanto (http://mientrastanto.org/quienes-somos)

9 Teina (n. ${ }^{\circ}$ 16, 2007) (http://www.revistateina.es/teina/web/teina16/dos6.htm)

10 Fundación de Investigaciones Marxistas (http://www.fim.org.es/01_01.php). 
O texto do Manifesto vai precedido dunha introdución do profesor Ramón Máiz Suárez, catedrático de Ciencias Políticas e da Administración da Facultade de Ciencias Políticas e Sociais da USC. O teor desta introdución contrasta, como se verá, cos prólogos de natureza político-ideolóxica que preceden as versións partidistas publicadas por Abrente e a Fundación Federico Engels. Nunha liña académica propia dun profesor universitario, estas 23 páxinas trazan a traxectoria de Marx, definido desde a primeira liña como un "intelectual" (p. 5), expoñen a xénese do Manifesto desde o punto de vista da filosofía política e ofrecen un repaso historiográfico aséptico do contexto en que se publicou, centrado nas revolucións europeas de 1848 .

Segue unha breve nota do tradutor onde trata sobre a problemática que supón escoller a versión orixinal e onde define o seu achegamento metodolóxico:

Tratándose dun texto de alto significado político, e con moito impacto a través da historia, cómpre ter moito coidado para evitar distorsións; por iso tamén se intentou entregar unha tradución o máis literal posible. Presentar unha versión 'amañada' non é, desde logo, o xeito máis adecuado, xa que ocultaría os problemas non resoltos e suporía a existencia de alguén que determinase o tipo de amaño, e ¿como se podería xustificar unha autoridade tal que eliminase o carácter histórico do texto? (NdT: 31$)$

Sen entrar a debater o acertado ou non do concepto de 'tradución literal' (véxase, por exemplo Ordudari, 2007), xunto coa introdución, esta nota serve a función paratextual de lexitimar a publicación como académica e filoloxicamente válida, xustificando a súa inclusión nunha colección formada por unha serie de obras clásicas da filosofía.

Curiosamente, na súa tradución da famosa frase de peche do Manifesto, Franck Meyer (Xerais, 1998: 85 e 2014: 97) rompe coa fórmula canonizada utilizada nas outras versións, ao optar por "Proletarios de todos os países, xuntádevos!". Esta decisión podería vir motivada por varias razóns: o descoñecemento da formulación habitual/tradicional (pouco probábel); un afán de harmonización coa tradución da Internacional en galego: "Axuntémonos todos, é a loita final" (tamén pouco probábel, mais non imposíbel); ou un desexo de fuxir da coñecida tradución española "Proletarios de todos los países, uníos!".

\subsection{Abrente (1998)}

Trátase dunha edición abertamente partidista, xa que que Abrente Editora é a "estrutura editorial de Primeira Linha [cuxo] objectivo e contribuir para a formaçom 
da militáncia revolucionária galega entendida num senso amplo"11. O Manifesto figura como a primeira obra escollida para lanzar a súa colección Biblioteca do Marxismo-Leninismo con motivo do 150 aniversario do Manifesto Comunista, tal e como se anuncia na contracapa.

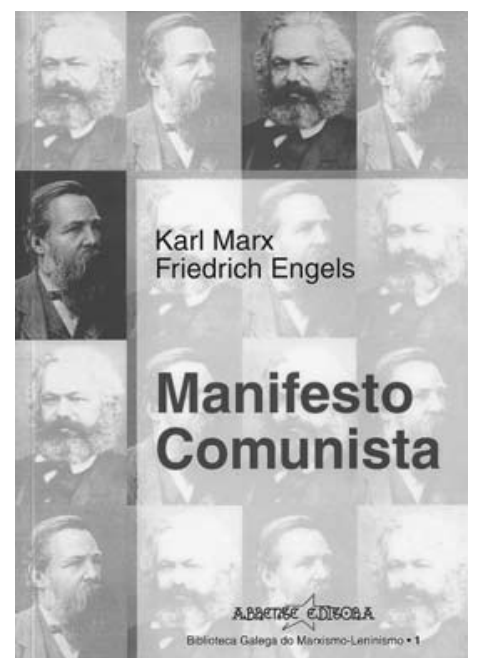

Fig. 5: Capa da primeira edición de Abrente, 1998 (14 x $20 \mathrm{~cm} .82$ páxinas).

Á diferenza de todas as outras edicións, aínda que se recorre no Prólogo ao termo 'tradución', as edicións publicadas por Abrente non foron traducidas directamente do alemán:

Esta nova traduzón a [sic] nosa língua non foi feita directamente do alemán como as anteriores, pois non é mais que unha adaptazón ao galego-portugués utilizado na Galiza da primeira traduzón "em língua portuguesa, legal ou não, em Portugal ou no Brasil (pelo menos que saibamos), estabelecida directamente sobre os originais, em alemão e inglês" realizada polas Edições Avante en Marzo de 1975, basicamente a partir da edizón alemá de 1890. Esta singular traduzón que foi confrontada e cotexada con outras das realizadas en portugués, concretamente a da Colecção Toupeira editada en Luanda, Angola, en 1975, e a da Editora Escriba, publicada en São Paulo, Brasil, en 1968 [...]. (Prólogo: 16)

11 Abrente editora (http://www.primeiralinha.org/abrenteditora.htm) 
Como ben se indica no Prólogo, a posíbel impresión de falta de rigor filolóxico ou valor tradutivo non mingua a validez da 'tradución', xa que a finalidade da publicación non é outra que política:

[...] a edizón deste livro que tés nas tuas maos [...] non ten como obxectivo realizar unha análise academicista, nen estilística, dun ensaio clásico, tampouco abordá-lo desde unha leitura histórica ou filolóxica, pois non está concebido para ser utilizado como texto universitário [...]. Esta edizón vai precisamente dirixida aos mesmos homes e mulleres para os que K. Marx e F. Engels escrevéron o conxunto da sua excepcional obra: a clase obreira e o conxuntos das camadas populares, para que tomen consciéncia da sua opresón e luiten pola sua necesária emancipazón. (Prólogo: 16).

Outro trazo paratextual que distingue as versións de Abrente editora das demais radica na escolla dunhas normas ortográficas reintegracionistas heterodoxas, isto é, diferentes das Normas Ortográficas e Morfolóxicas do Idioma Galego (NOMIG) -a miúdo chamadas 'oficiais'- que predominan na maioría dos ámbitos tras a súa aprobación polo ILG e a RAG en 1982. Así, esta primeira edición opta por usar a denominada normativa de 'mínimos' elaborada pola Asociación Sócio-Pedagóxica Galega (AS-PG), concretamente, unha variedade pouco estendida dentro deste espectro normativo (véxase Álvarez Cáccamo e Herrero Valeiro, 1996) máis próximo ao portugués, isto é con à, -zón e -ui-. Esta elección vén motivada por razóns ligadas ao ámbito político, ao tratarse dunha normativa utilizada principalmente por $A$ Nosa Terra e tipicamente asociada co Bloque Nacionalista Galego $(\mathrm{BNG})^{12}$, formación política dentro da cal estaba integrada Primeira Liña (máis tarde 'Primeira Linha') naquela altura.

Normalmente, traducir do portugués ao galego ten un propósito diferencialista (Baxter, 2002), isto é, proxectar e difundir unha imaxe do galego como lingua diferente e independente do portugués. Desde o punto de vista da defensa da unidade lingüística do galego-portugués como diasistema lingüístico no cal se basea o discurso reintegracionista, resulta, pois, cando menos curioso 'traducir' (máis ben, 'reortografar') desde unha variedade galego-portuguesa (português padrão) para outra (galego reintegrado). Poderíanse barallar dúas razóns que motivan esta práctica neste caso: por un lado, un afán por sacar unha edición partidista propia para o 150 centenario, aínda sen dispor da capacidade e/ou o tempo necesarios para o traducir directamente do alemán ex novo e, polo outro, unha vontade de tecer vínculos lingüísticos -aínda que, coidamos, de xeito mal concibido- entre o galego e o portugués na liña ideolóxica do Partido en cuestión.

12 O BNG abandona a normativa de mínimos tras a reforma das NOMIG en 2003. Ao saír do BNG, Primeira Liña adopta a normativa reintegracionista de 'máximos' da AGAL. (Véxase máis adiante). 
No que atinxe ao resto dos elementos textuais físicos, a capa confórmaa un mosaico dos retratos 'canónicos' habituais de Marx e Engels en tons rosados tirando a vermello. Na solapa interior inicial, reprodúcense os mesmos retratos, xunto cunha nota biográfica que destaca o papel revolucionario de Marx e o papel (algo secundario) de Engels como "difusor privilexiado do seu pensamento". A solapa interior final retoma dous parágrafos do Prólogo onde, para alén de explicar a escolla do texto fonte en portugués, se expoñen os motivos da publicación:

No 150 aniversário da sua publicazón [...] a esquerda revolucionária independentista de matriz marxista-leninista cumpre-lle o dever de fazer realidade o desexo d@s comunistas galeg@s: poder ler, estudar e compreender a teoria libertadora de Marx, Engels, Lenine, o Che, e outr@s revolucionári@s na nosa língua. ABRENTE Editora inicia con esta obra capital para a emancipazón da clase operária, o primeiro livro da Biblioteca Galega do Marxismo-Leninismo. (Solapa interior final)

Trátase de reivindicar $O$ Manifesto como ferramenta política actualmente vixente, ao mesmo tempo que se avala o partido que o publica como de "esquerda revolucionária independentista de matriz marxista-leninista":

Este livro como o conxunto da obra marxista, parafraseando a Lenine, é ante todo, unha guia para a aczón, pois "non existe movimento revolucionário sen teoria revolucionária". É necesário seguir organizando a disidéncia subversiva ao capitalismo, construindo o proxecto revolucionário que dirixa à clase obreira, como vanguarda do Povo Traballador Galego, cara os (sic) obxectivos estratéxicos da Independéncia Nacional e o Socialismo; pois nunca devemos esquecer que o dever de tod@revolucionári@ é fazer a Revoluzón. (Solapa interior final)

No interior do libro, antes da folla de rostro propiamente dita, na parte superior da primeira páxina encima do título abreviado Manifesto Comunista, aparece a frase “Proletári@s de todos os países unide-vos!” Desde o punto de vista paratradutivo, resulta interesante o uso innovador e rompedor do arroba como marca do xénero inclusivo, pois anuncia de xeito moi visíbel parte da ideoloxía do partido responsábel, isto é, o seu compromiso coa loita feminista. No entanto, este recurso lingüístico só se aplica ás partes editoriais do Manifesto, p.e. o prólogo, e non se fai extensíbel á tradución do Manifesto en si, mesmo na frase final onde aparece traducido como "Proletários do mundo", como se, dalgunha maneira, o uso do pseudoxenérico no alemán orixinal fose sacrosanto e non só unha convención gramatical susceptíbel de ser actualizada nunha tradución moderna.

O índice vén precedido dunha reprodución da portada da primeira edición en alemán do Manifesto e, despois do sumario e antes do prólogo editorial, aparecen tres citas de Lenin extraídas das súas obras Karl Marx, O Estado e a Revolución e 
O Marxismo e o Estado, respectivamente. Para alén de se trataren de citas sobre o Manifesto, xunto co nome da colección da cal o volume fai parte (Biblioteca Galega do Marxismo-Leninismo), a inclusión de citas de Lenin permite afianzar o marxismo-leninismo como ideoloxía reitora do partido: "Ratificamos a tradiçom comunista da que nos reclamamos e a nossa indiscutível natureza de força marxistaleninista." (VI Congreso, 2015)

Antes dos Prefácios ás edicións orixinais, aparece o Prólogo do Comité Central de Primeira Liña $(M L N)^{14}$, oito páxinas de marcado carácter político partidista, como o seu propio nome anticipa. Por exemplo, moi a pesar de pretender fuxir dun texto “carregado de sesudas notas críticas ao pé de páxina, que desde unha visión neutral aplican sesgados, restrinxidos e descalificadores comentários ideolóxicos" (p. 16), tres páxinas máis adiante non dubida en 'esclarecer' que "Apesar de que a revoluzón socialista, após o fracaso das experiéncias do autoritarismo burocrática estalinista [...]" (p. 19), o que dista moito de ser unha posición ideolóxica 'neutral'.

\subsection{Abrente (2004)}

Seis anos após a primeira edición cunha tiraxe de 1000 exemplares, Abrente Editora publica unha segunda edición cunha nova de tiraxe máis limitada de 500 exemplares.

Conta cunha nova portada onde predomina o escarlata, ocupada case na súa totalidade por un gran retrato pétreo só de Marx. A solapa interior inicial é a mesma que na primeira edición, mentres que a solapa interior final recolle as obras publicadas até a data por Abrente organizadas en catro coleccións: Biblioteca Galega de Marxismo-Leninismo, Internacional, Documentos e Textos Políticos, e Construirmos Galiza. A inclusión da terceira desta coleccións permite dar a coñecer e espallar o ideario propio do Partido, ao incluír, por exemplo, as Resoluçons do I, II e III Congresos de Primeira Linha.

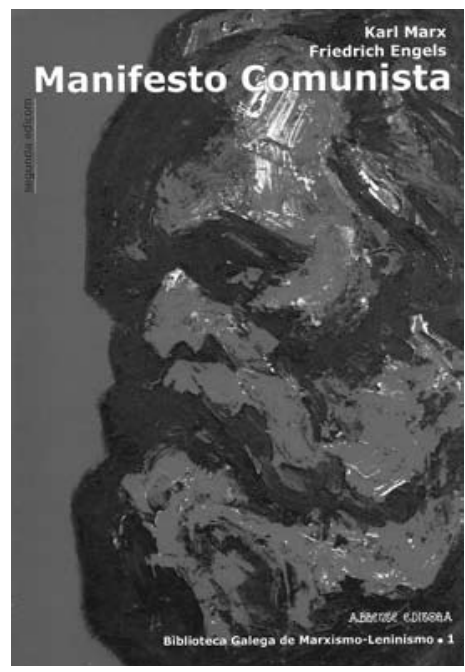

Fig. 6: Capa da primeira edición de Abrente, 2004 (14 x $20 \mathrm{~cm} .84$ páxinas).

13 Acordos do $6^{\circ}$ Congresso de Primeira Linha (https://galiza.lahaine.org/acordos-do-6o-congresso-de) 14 Movimento de Libertaçom Nacional. 
Aínda que o texto en si é o mesmo, desde o punto de vista paratradutivo diferénciase claramente da edición antes ao utilizar o "padrom lingüístico plenamente reintegrado" (p. 13) da Associaçom Galega da Língua (AGAL) seguindo o cambio político na opción normativa da Primeira Liña (desde entón Primeira Linha). Esta mudanza non é filolóxica, mais propiamente ideolóxica-política e coincide coa saída da organización do BNG e o seu distanciamento a respecto del:

Nascemos como organizaçom no seio do BNG, pensando que era viável construir umha corrente revolucionária marxista no seu interior. Naquela etapa, ainda sendo reintegracionistas umha boa parte da militáncia inicial, incluídos alguns sócios da AGAL, tentamos evitar um choque com as práticas maioritárias no BNG, seguramente com umha certa dose de ingenuidade, visto com a perspectiva que dam os anos. [...] Quando chegamos à conclusom de que a nossa presença no BNG estava esgotada [...] o I Congresso de Primeira Linha adoptou já o padrom da AGAL, sendo imediatamente adoptado no próprio Abrente e nas restantes publicaçons partidárias. (Carlos Morais, $2008)^{15}$

Aínda que a normativa da AGAL a utilizan persoas en organismos dos máis variados ámbitos, fica estreitamente ligado -sobre todo naquela altura- ao movemento 'independentista', dentro do cal se inscribe Primeira Linha.

Para alén de coincidir co 80 aniversario da morte de Lenin (contracapa), incidindo no reforzamento da imaxe do partido como marxista-leninista, esta escolla normativa está lonxe de ser meramente accesoria ou tanxencial, pois trátase, máis ben, da primeira razón que motiva unha nova edición para visibilizar publicamente esta mudanza de orde ideolóxica-lingüística.

A maiores de reproducir o prólogo orixinal da edición de 1998, esta segunda edición inclúe un novo Prólogo à ediçom galega de $2004^{16}$, moito máis curto, de tan só tres parágrafos, que incide en que "validade e actualidade fundamental do ideário que sintetiza torna imprescindível o seu estudo por parte das comunistas e os comunistas galeg@s", pondo en destaque o duplo vertente do pensamento política de Primeira Linha: "que em pleno século XXI luitamos pola plena emancipaçom humana através da própria libertaçom da Galiza como realidade nacional ameaçada" (p. 13).

15 Secretario Xeral de Primeira Linha (1998-2014), nunha entrevista para Portal Galego da Língua (http://pglingua.org/noticias/entrevistas/506-lo-partido-ao-servico-da-linguar-entrevistamos-carlosmorais-noa-rios-e-igor-lugris-do-conselho-de-redaccom-de-abrente-periodico-de-primeira-linha)

16 A data de 2003 figura erroneamente no índice. 


\subsection{La Voz de Galicia (2005)}

Aínda sendo unha reedición da tradución feita por Franck Meyer en 1998 para Xerais, os paratextos que engloban esta edición indican que se trata dun obxecto (case máis que un libro para ser lido) cunha función diferente non só das edicións de Xerais, mais tamén de todas as outras.

Pertence a unha serie coleccionábel titulada Biblioteca Galega de Clásicos Universais co-editada en 2005 por La Voz de Galicia e sete editoras galegas xunto coa Biblioteca Virtual Galega (Bragado, 2013: 224) conformada por 40 obras reeditadas en galego (véxase Luna Alonso, 2006), sobre todo de literatura anglófona e francófona e, en moito menor medida, alemá, rusa e residualmente en latín, grego, italiano ou español.

Esta é a única edición publicada en galego cunha capa dura cuxa capa loce unha imaxe puramente estética e común a toda a colección, ${ }^{17}$ característica típica dunha serie coleccionábel onde o que importa é a uniformidade estética ao colocar uns ao lado dos outros en fila por orde numérica no andel. A imaxe que mostra un detalle dun antigo edificio de pedra non mantén unha relación coa temática de calquera das obras, incluído o Manifesto, mais serve, pola contra, para evocar o fío temático que dá sentido á colección: unha biblioteca erudita que lembra, por exemplo, a de Fonseca en Santiago de Compostela.

Neste caso, O Manifesto tórnase, en definitiva, un obxecto en forma de libro; un elemento decorativo culto, cuxa función non é tanto a de ser lido dun ou outro xeito (clásico da literatura, da filosofía ou manual de acción...) que ha de ser visto e apreciado como símbolo de erudición.

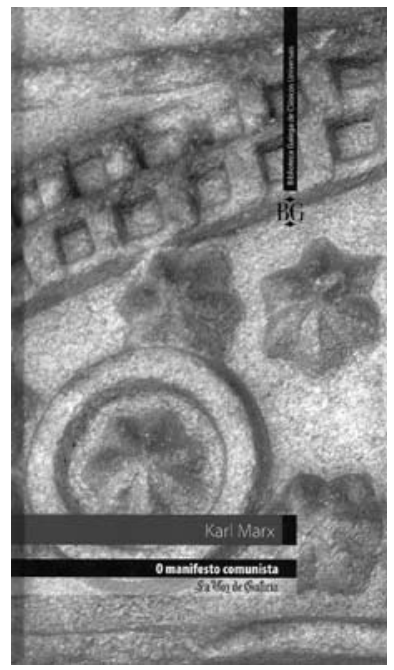

Fig. 7: Capa da edición de $L a \mathrm{Voz}$ de Galicia, 2005 (13 x $22 \mathrm{~cm} .94$ páxinas).

Sen entrar aquí a valorar até que punto a literatura case exclusivamente europea e masculina -só figuran catro mulleres na colección- se pode considerar 'universal', nin en que medida Graham Greene ou Agatha Christie se poden considerar 'clásicos' ao mesmo nivel, por exemplo, de Shakespeare, Goethe ou Dostoievski, a publicación das obras desta colección conformada por 'clásicos universais' cumpre un tipo de

17 Excepto o volume d'O principiño que insire as ilustracións orixinais de Saint-Exupéry por vontade do autor para calquera edición. 
función relacionado coa planificación do status do galego co fin de o realzar como lingua de prestixio:

[...] é a primeira vez que se nos presenta un fenómeno editorial tan importante para a historia da tradución cara ao galego, así como para o desenvolvemento do noso sistema literario e cultural. [...] este fenómeno editorial tivo que supoñer unha magnífica oportunidade para contribuír á normalización lingüística e cultural, dando a coñecer ao público en xeral a existencia de traducións en galego [...] (Luna Alonso, 2006: 187)

Isto explica, ademais, por que non se inclúe non só a introdución orixinal do profesor Máiz Suárez, senón tampouco a nota do tradutor, xa que cumpre as súas funcións sen sequera ser aberto nin, moito menos, lido. Neste caso, pódese dicir que o paratexto prima mesmo sobre o propio texto.

\subsection{Fundación Federico Engels (2009)}

A Fundación Federico Engels, de orientación trotskista, publicou versións do Manifesto nas catro linguas do Estado: español (1996, reed. 2004), catalán (2005, reed. 2013), vasco (2007) e galego (2009). No entanto, cando menos no caso do galego, as versións en linguas co-oficiais demostran unha certa relación de dependencia a respecto da versión matriz en lingua española, tal e como se analiza máis adiante. Como se pode comprobar no seu catálogo ${ }^{18}$, até 2016 editou tamén unha serie de libros de autoras e autores como Lenin, Rosa Luxemburg ou James Connolly, tanto en catalán como vasco, mais ningunha alén da que nos ocupa en galego, o que resulta posibelmente indicativo do escaso grao de implantación territorial da organización política ligada á Fundación.

As traducións foron realizadas polo 'Grupo de Tradutores' da Fundación (colofón), polo que se poden cualificar asemade de 'anónimas' e 'partidistas', a estas alturas, lonxe de ser

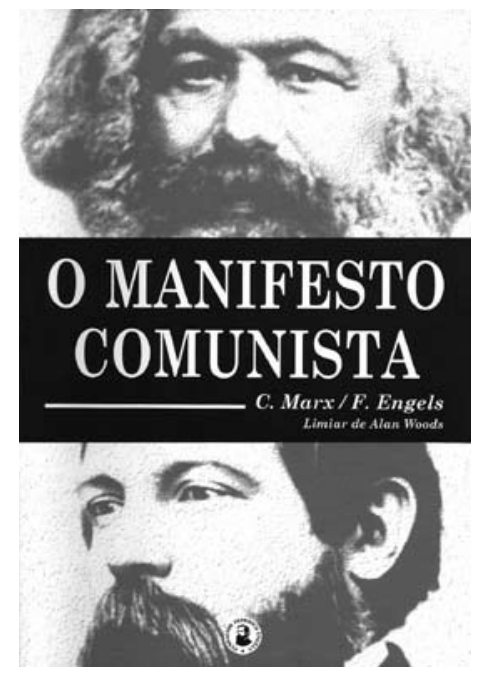

Fig. 8: Capa da edición da Fundación Federico Engels, 2009 (13 x $19 \mathrm{~cm} .88$ páxinas).

18 Publicaciones de la Fundación Federico Engels. Listado libros y revistas 2016 (http://www. fundacionfedericoengels.net/images/PDF/catalogo_libros_2016.pdf) 
comparábel co necesario grao de clandestinidade que levou a recorrer ao uso dun pseudónimo no caso da edición de Nova Galiza de $1976 .{ }^{19}$

Alén da capa de cor sepia, con retratos canónicos superpostos de Marx e Engels, e a contracapa, de cor vermella cunha cita-cuxa orixe exacta non se precisa-do primeiro capítulo do Manifesto centrado no papel do proletariado e a habitual reprodución da capa da primeira edición de 1884, esta versión está repleta de paratextos de grande interese que dan pistas acerca da intención da publicación.

Abre cun limiar de destacada importancia, ao ser esta a única versión en galego que anuncia a introdución e o seu autor na propia capa, inmediatamente debaixo do nome dos autores do propio Manifesto. O Limiar corre a cargo do activista e autor Alan Woods, Secretario da Corrente Marxista Internacional (International Marxist Tendency) e editor do político do sitio trotskista In Defence of Marxism ${ }^{20}$ que serve de referencia dixital do Partido. Aínda que no Estado español o partido existe co nome Lucha de Clases $^{21}$, é a organización Izquierda Revolucionaria ${ }^{22}$, da mesma tendencia trotskista fundada polo británico Ted Grant, a que se acha detrás da Fundación Federico Engels, tal e como recollen as páxinas finais do libro (ver abaixo).

Xa desde as primeiras liñas, este texto introdutorio deixa claro tanto a xustificación da publicación en si como a vixencia do propio Manifesto:

Estimado lector: Tes nas túas mans un dos documentos máis importantes da historia. A primeira vista, parece que a publicación dunha nova edición do Manifesto esixe una explicación. ¿Como se pode xustificar a reedición dun libro escrito hai case 150 años? Se botamos unha ollada a calquera libro burgués escrito hai un século e medio sobre os mesmos temas, darémonos de conta rapidamente que ese libro só terá un mero interese histórico, sen ningunha aplicación práctica. Pero o libro que nos ocupa é o documento máis moderno que existe. Velaquí unha análise profunda que explica, en moi poucas palabras, todos os fenómenos máis fundamentais da actual situación mundial. De feito, O Manifesto Comunista é incluso máis verdade hoxe [isto é, en 1996] ca en 1847 [...].

19 Esta 'discreción' non deixa de lembrar o razoamento detrás do anonimato dos membros da Comisión para a Tradución da Biblia do Novo Mundo encargada polas Testemuñas de Xehová, ao pedir que non se revelasen os seus nomes: "the producers do not choose to advertise themselves but let all the glory go to the Author of the Scriptures, God" e "should direct the reader [...] to [...] Jehovah God." The Watchtower, novembro 15, 1950, páx. 454 e decembro 15, 1974, páx. 768. (http://avoidjw.org/ magazines/)

20 'A Brief Biography of Alan Woods' no sitio Socialist Appeal (https://socialistappeal.org/analysis/ international/1017-a-brief-biography-of-alan-woods)

21 Lucha de Clases (http://www.luchadeclases.org/

22 Izquierda Revolucionaria (http://www.izquierdarevolucionaria.net/)

Revista Galega de Filoloxía, 2018, 19: 11-40

ISSN 1576-2661 / e-ISSN 2444-9121 (c) (i) () 
Trátase dun prólogo para a edición española da mesma editora do ano 1996, polo que xa era vello (máis de dez anos) no momento de se publicar esta versión en galego. Mantense moi probabelmente por tres razóns relacionadas entre si: por marcar o Manifesto como un texto político de plena vixencia e actualidade; por vincular directamente esta versión galega coa edición 'nai' en español que serve de texto de referencia para o Partido detrás da súa publicación, funcionando o texto español, dalgún xeito, de texto canónico de base desta -e posibelmente outrascorrente da $4^{\mathrm{a}}$ Internacional; e por ser o autor unha referencia e amigo do Partido, tal e como testemuñan varios libros da súa autoría e co-autoría xunto con Ted Grant publicados pola mesma editorial/partido que figuran anunciados nas páxinas finais desta edición do Manifesto Comunista.

Ao final da obra aparecen seis páxinas dedicadas a promocionar a Fundación Federico Engels, as súas publicacións e o seu xornal: a primeira inclúe información sobre os obxectivos da Fundación, xunto cunha ficha para se facer socio e as tarifas correspondentes; a segunda inclúe os índices da revista Marxismo Hoy, tamén xunto cunha ficha de subscrición coas tarifas; tres páxinas dedicadas a unha listaxe de obras das coleccións Clásicos del Marxismo, Crítica Comunista, Memoria Obrera e Cuadernos de Formación Marxista, todas elas en español excepto o Manifesto Comunista en catalán, e cuxos autores, sobre todo de Marx/Engels, Lenin, Rosa Luxemburgo, León Trotski, Alan Woods e Ted Grant, indican claramente cal é a tendencia política; e unha páxina final dedicada ao xornal mensual El Militante, xunto cunha ficha de subscrición e os contactos na Galiza.

Como no caso das edicións de Abrente, unha análise dos paratextos indica que esta edición do Manifesto cumpre ostensibelmente unha dupla función: por un lado, a edición dunha versión de referencia para seguidores trotskistas (pensamos, máis unha vez, no paralelismo coa Tradución do Novo Mundo das Santas Escrituras das Testemuñas de Xehová); e propagandística, na procura de novas lectoras e, eventualmente, militantes.

\subsection{Xerais (2015)}

Por último, reeditouse a tradución de Franck Meyer de 1998 coa mesma introdución e notas do tradutor dentro da subcolección dos libros de peto Libro X, composta dunha vintena de libros de tipo ensaístico. Coa excepción do Manifesto e Viaxe por Galicia de George Borrow (extraído do seu libro The Bible in Spain), todos eles foron escritos orixinariamente en galego por autor@s coñecid@s, entre el@s (na súa enorme maioría, dito sexa de paso, homes), Mercedes Queixas Zas (De pergamiños, follas voandeiras e libros ao.gal), Suso de Toro (Humildar. Rituais 
despois de Deus e O país da brétema), Xavier Navaza (Marcas. Signo, comunicación e consumo na era da simulación e $O$ Miño. Un caudal de historia) ou Anselmo López Carreira (Pedro Petouto). A temática é variada, onde dificilmente se entende o encaixe que pode ter, por exemplo, E logo, temos razóns para ser nacionalistas? de Henrique de Bosque Zapata, Como falar e escribir en galego con corrección e fluidez de Carlos Callón, $A$ alternativa está aquí de María Reimóndez ou o propio Manifesto Comunista c'O libro dos cócteles de David Ortiz Borrás ou $O$ polbo e a súa cociña. 67 receitas da cociña tradicional familiar de Matilde Felpeto Lagoa, para alén de se tratar de obras de non ficción dunha extensión relativamente curta (formato peto). Ao ser inserido nesta colección tan heteróclita, o Manifesto perde potencialmente o seu valor como obra de acción política.

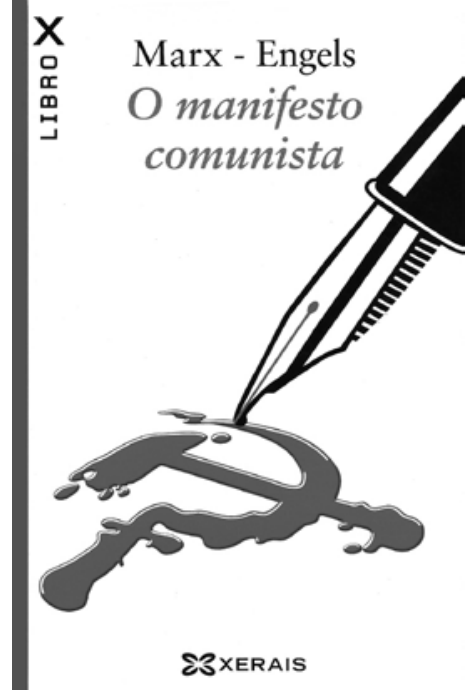

Fig. 9: Capa da segunda edición de Xerais, 2015 (13 x $20 \mathrm{~cm} .125$ páxinas).

A contracapa recolle o mesmo texto de Capella que a edición anterior, ao cal se engade unha biografía resumida de Marx e Engels, de corte netamente máis bibliográfica a respecto das súas obras, á diferenza, por exemplo, das biografías de corte político, das solapas de Abrente Editora.

Mais, a pesar das similitudes básicas entre esta segunda edición e a edición anterior, desde o punto de vista paratextual, non se pode considerar que se trata dunha simple reedición sen máis. Mención á parte merece esta edición debido, xustamente, a un impresionante e singular elemento paratextual fundamental que conforma a imaxe da capa, cuxo deseño corresponde a Manuel Vigo. En efecto, é a única edición en lingua galega que ostenta unha imaxe, se non claramente anticomunista, polo menos transmisora dunha mensaxe extremadamente negativa a respecto do legado do Manifesto. A imaxe consiste nunha pluma (autoría do libro) que acaba de debuxar un fouce e martelo (símbolo internacionalmente recoñecido do comunismo, a pesar de que de creación moi posterior ao propio Manifesto, ao xurdir coa súa forma actual após a Revolución Rusa de 1917) cunha espesa e coagulada tinta vermella. A mensaxe non podería ser máis clara: a historia do Comunismo que iniciaron Marx e Engels coa publicación do Manifesto escribiuse con sangue. 


\section{Conclusións}

Unha focaxe paratradutiva permite abordar un texto, entendido como obxecto global, no seu conxunto, en vez de analizar a 'tradución' en si como se se puidese separar do soporte e discursos que o rodean, pois, como ben apunta Yuste Frías (2015: 327) "sin paratexto, el texto no existe" e, por tanto, sen paratradución a tradución non existe.

Isto fica patente ao analizar comparativamente os paratextos que engloban e completan as diferentes edicións do Manifesto do Partido Comunista publicadas en galego, xa que, se ben se trata a priori do 'mesmo' texto, todo indica que varían considerábel e significativamente as súas pretendidas funcións e intencionalidades, tal e como se transmiten a través dos paratextos ás receptoras/lectoras potenciais, autónoma e independentemente do texto de partida.

A análise paratradutiva levada a cabo permite dividir as diferentes versións en lingua galega grosso modo en dúas categorías principais segundo a súa implícita e latente intencionalidade funcional: por un lado, as edicións que retratan o Manifesto como un clásico da filosofía, un documento principalmente de valor histórico e/ou literario (Xerais) ou simbólico (La Voz de Galicia); e, polo outro, aquelas edicións que se proxectan como manuais políticos de actualidade e onde se pode distinguir, á súa vez, entre as versións partidistas (Abrente e a Fundación Federico Engels e, en menor medida, Nova Galiza) e as non-partidistas (Akal). Porén, as categorías non son estancas e pode existir, como xa se indicou no momento de analizar as versións editadas por Xerais, elementos que fan que pertenza a ambas as categorías.

Este tipo de análise é todo menos irrelevante no caso dunha obra como O Manifesto Comunista que tanto marcou e segue a marcar o pensamento e a historia da humanidade. 


\section{Apéndice}

Listaxe completa das traducións do Manifesto do Partido Comunista a linguas noncastelás do Estado español:

\section{1) Asturiano}

Manifiestu del Partíu Comunista (1999): Trad. Pilar Fidalgo Pravia (Mieres: Editora del Norte).

\section{2) Catalán}

Manifest del Partit Comunista (1930): Trad. E. Granier-Barrera. Barcelona (Barcelona: Arc de Barà).

Manifest del Partit Comunista (1936): Trad. Pau Cirera (Barcelona: Atenea).

Manifest comunista. Manifest inaugural i estatuts de l'Associació Internacional dels Treballadors. (1937): Trad. Anón (Barcelona: Edicions Europa-América).

Manifest del Partit Comunista (1948): Trad. Amadeu Bernadó (París: Lluita).

El Manifest Comunista (1997): Trad. Jordi Moners i Sinyol (Barcelona: La Magrana).

El Manifest Comunista (1998): Trad. Jordi Moners i Sinyol (Sueca: Ajuntament de Sueca). [Reedición da edición publicada por La Magrana].

El Manifest Comunista (2015): Trad. Jordi Moners i Sinyol (Manresa: Tigre de Paper). [Reedición da edición publicada por La Magrana].

Manifest del Partit Comunista (1976): Trad. Pau Cirera (Barcelona: Undarius).

Manifest del Partit Comunista (s.d.): Trad. Carles Castellanos. [Non de dispón de máis información]. Dispoñíbel en https://jovesaltmaresme.files.wordpress.com/2015/03/ manifestcomunista_marx_engels.pdf [consult. 20.01.2018].

El Manifest Comunista (2013) [2005]: Trad. Anón. (Madrid: Fundación Friedrich Engels).

Manifest del Partit Comunista (s.d.): Trad. Anón. (Sen lugar: Edicions Internacionals Sedov, editorial de Germinal - Nucli en defensa del marxisme). [Posibelmente só publicado en liña. http://grupgerminal.org/?q=system/files/ManifestComunistaMarxiEngels1948NorantaanysdelManifestTrotski.pdf].

\section{3) Vasco}

Komunista alderdia-ren agiria (1971): Trad. Anón. (París: Librairie du Globe).

Alderdi Komunistaren Manifestua (1980): Trad. Xabier Quintana. Donostia: Editorial Hordago). [Versión bilingüe español/vasco]. 
Alderdi komunistaren manifestua. (1998): Trad. Xabier Kintana (Donostia: Jakin). Manifestu Komunista (2007): Trad. Anón. (Madrid: Fundación Federico Engels).

Komunista Alderdia-ren Agiria (2010): Trad. Descoñecido (Sen lugar: Kimetz - Euskal Herriko Erakunde Komunista). [Texto trilingüe vasco, español e francés. Non se dispón de máis información: http://datos.bne.es/edicion/a4990714.html].

\section{4) Galego}

Manifesto do Partido Comunista (1976): Trad. Xoan Andeiro (Lisboa: Nova Galiza). Manifesto do Partido Comunista (1976): Trad. Isaac Alonso Estravís (Madrid: Akal).

O Manifesto Comunista (2015) [1998]: Trad. Franck Meyer (Vigo: Xerais).

O Manifesto Comunista (2005): Trad. Franck Meyer (A Coruña: La Voz de Galicia). [Reedición da primeira edición publicada por Xerais].

Manifesto Comunista (2004) [1998]: Trad. Anón. (Santiago de Compostela: Abrente). [Primeira edición na normativa de mínimos; segunda na normativa de AGAL].

O Manifesto Comunista (2009): Trad. Anón. (Madrid: Fundación Federico Engels).

\section{Referencias bibliográficas}

Academia Galega da Língua Portuguesa (2015). Membros Numerários. Dispoñibel en https://academiagalega.org/academia/membros-numerarios.html [consult. 20.01.2018].

Álvarez Cáccamo, C. / Herrero Valeiro, M. J. (1996). “O continuum das normas escritas na Galiza: Do espanhol ao português”, Agália, 46, 143-156.

Argemí, L. (1999). "El Manifest comunista en la història del pensament", Papers. Revista de Sociologia, 57, 11-20.

Baxter, R. N. (2002). "El paper de la traducció en la consolidació de la percepció social del gallec com a Abstandsprache", Quaderns: revista de traducció, 7, 167-181.

Baxter, R. N. (2013). "Interpreting and minority language planning and policy. Galician as a case study", Language Problems \& Language Planning, 37:3, 227-248.

Berman, Marshall (2011). "Introduction", The Communist Manifesto. Londres: Penguin.

Boyer, G. R. (1998). "The historical background of the Communist Manifesto", Journal of Economic Perspectives, 12:4, 151-174.

Bragado, M. (2013). "Tradución e literatura galega (II)”, en Mosquera Carregal, X.M. (ed.), Lingua e Tradución. IX Xornadas sobre Lingua e Usos, 221-225. A Coruña: Universidade da Coruña. 
Cruces, S. (1993). “A posición da literatura traducida no sistema literario galego", Boletín Galego de Literatura, 10, 59-65.

García González, Marta (2005). "Translation of minority languages in bilingual and multilingual communities". En Branchadell, A. / West, L. M. (eds.), Less Translated Languages 105-123. Amsterdam: John Benjamins.

Garrido Vilariño, X. M. (2005). “Texto e Paratexto. Tradución e Paratradución”, Viceversa, 9-10, 31-39.

Gasch Grau, E. (1975). "Difusió del Manifest comunista a Catalunya i Espanya (18721939)", Recerques: Història, economia i cultura, 5, 21-30.

Genette, Gérard (1987). Seuils. París: Éditions du Seuil.

Luna Alonso, A. (2006). “A Biblioteca Galega dos Clásicos universais”, Viceversa, 12, $187-201$.

Mota Muñoz, J. F. (2010). “Un espectre atemoreix Europa: l'espectre del comunisme'. Vuitanta anys de la primera traducció al català del Manifest comunista", El bloc de l'Associació Catalana d'Investigacions Marxistes (ACIM). http://www.fcim. cat/bloc/2010/10/05/un-espectre-atemoreix-europa-lespectre-del-comunismevuitanta-anys-de-la-primera-traduccio-catalana-del-manifest-comunista/ [consult. 20.01.2018].

Nord, C. (2012). "Paratranslation - a new paradigm or a re-invented wheel?", Perspectives, 20:4, 399-409.

Ordudari, M. (2007). "Translation procedures, strategies and methods", Translation Journal 11:3, sen páx. Dispoñibel en http://translationjournal.net/journal/41culture. htm [consult. 20.01.2018]

Pérez Prieto, V. (s.d.). Biografia. A Coruña: Asociación de Escritores en Lingua Galega. http://www.aelg.org/resources/centrodoc/members/works/pdfs/OB_obra3956_F4_3. pdf [consult. 20.01.2018].

Rich, A. (2015). "Preface". En Shnookal, D. (dir.), Manifesto: Three Classic Essays on How to Change the World (Ernesto Che Guevara, Friedrich Engels, Karl Marx, Rosa Luxemburg). Washington: Ocean Press.

Stratford, M. \& Jolicoeur, L. (2014). "La littérature québécoise traduite au Mexique: trois anthologies à la Foire internationale du livre de Guadalajara", Meta, 59:1, 97-123.

Taylor, A. J. P. (1967). “Introduction”, The Communist Manifesto. Londres: Penguin.

Woodsworth, J. (1996). "Translation and the promotion of national identity", Target, 82, 211-238.

Yuste Frías, J. (2015). "Paratraducción: la traducción de los márgenes, al margen de la traducción”, Documentação de Estudos em Lingüística Teórica e Aplicada, 31, 317-347. 
Yuste Frías, J. (2010). "Au seuil de la traduction: la paratraduction". En Naaijkens, T. (ed.), Event or Incident. Evénement ou Incident. On the Role of Translation in the Dynamics of Cultural Exchange. Du rôle des traductions dans les processus d'échanges culturels, 287-316. Bern: Peter Lang. 